\title{
Basel II, Sovereign Ratings and Transfer Risk External versus Internal Ratings
}

\author{
by \\ Stijn Claessens and Geert Embrechts*
}

07 May 2002

\begin{abstract}
Basel II puts great emphasis on external ratings, including from rating agencies, to quantify credit risks, but it also allows financial institutions to use their internal risk ratings. This is also the case for international lending, but following recent emerging markets' crises, the quality of sovereign ratings has received much criticism. At the same time, little is known about the quality of internal ratings of country risk. Using data from a major international bank, we assess the relative performance of internal and external country ratings. We find that internal and external ratings are driven by similar factors and both underestimate "event risks", but that external ratings are somewhat slower in adjusting to a financial crisis.
\end{abstract}

University of Amsterdam and Rabobank International, the Netherlands respectively. For presentation at the conference Basel II: An Economic Assessment, Bank for International Settlements, Basel, 17-18 May 2002, organized by the Centre for Economic Policy Research, Journal of Financial Intermediation, and the Basel Committee on Banking Supervision. The opinions do not necessarily express those of the Rabobank. The authors would like to thank Peter Boswijk and Martijn Krijger for help with the statistical analysis and Michiel van Voorst, Leendert Colijn, Adriaan Kukler, Frank Ligtenberg and Leonhardt van Efferink for comments on an earlier version. 


\section{Introduction}

In January 2001 the Basel Committee on Banking Supervision issued a consultative document on a new Basel Capital Accord (the 'Basel II' proposal). Under the standardized approach, Basel II puts greater emphasis on the role of external ratings, including from rating agencies, to assess credit risks. At the same time, Basel II also increases the scope for financial institutions to use their internal risk ratings under the more advanced approach, provided a number of criteria are being met by the particular financial institution.

Regulatory authorities are expected to request banks to apply the new risk management concepts not only to domestic lending but also to international lending in the next few years. Although not (yet) in particular extensively dealt with in the Basel II proposal, country and transfer risk are major sources of credit risk for international lending. For the standardized Basel II approach, sovereign ratings by rating agencies are expected to play an important role in the measurement of credit risk. The quality of sovereign ratings has received much criticism, however, particularly for emerging markets and following the East Asian financial crises. This may make internal ratings more attractive.

Little is known, however, on how internal ratings perform in assessing country risk and how they compare to external ratings. Are internal ratings driven by similar or different considerations of country risk? Do internal ratings perform a better job in predicting rating changes than external ratings do? Which set of ratings performs best in assessing expected default frequencies? Are internal ratings more or less volatile than external ratings? The purpose of this paper is to examine how country risk ratings (and transfer risk in particular) may fit into the Basel II proposals and Economic Capital models, how external and commercial banks' internal rating behavior can be explained, and how external ratings compare to internal ratings.

To do so, we first review the notion of country risks. We argue that, in the current environment, sovereign risk is but one component of country risk that can lead to credit risks. Transfer risk is all the more important, also as under Basel II it is the only identified category of country risk. We next review the literature on sovereign ratings to identify the factors driving country risk. We also review the criticism of sovereign ratings following the East Asian financial crisis. We then assess the (relative) performance of internal and external ratings using a long series from a major bank active in international lending. We find that internal transfer and external sovereign credit ratings are driven by similar factors, but with different weighting. We also find that external ratings are worse in adjusting to crises. The findings suggest that internal ratings can be as good or even better a tool to assess country risk as external sovereign ratings are.

The outline of the paper is as follows. In the first section, the concepts of country risk, transfer risk and sovereign risk are defined. In the second section, the Basel II proposals regarding sovereign ratings and transfer risk, and new risk management techniques, such as the Economic Capital approach, are briefly discussed. The third 
section examines the rating methodologies used for sovereign and transfer risks. Since Basel II and Economic Capital models leave ample room for a statistical approach to risk, the explanatory powers of sovereign and transfer rating models are checked. Also, the transfer rating migration over time are examined and compared to sovereign rating behavior. The last section concludes.

\section{The concepts of country and transfer risks}

We start with a commonly used definition of country risk, as provided for example by Nagy (1984): 'Country risk is the exposure to a loss in cross-border lending, caused by events in a particular country which are—at least to some extent—under the control of the government but definitely not under the control of a private enterprise or individual.' It is important to realize that in this definition all forms of cross-border lending in a country—whether to the government, a bank, a private enterprise or an individual—are included. Country risk is therefore a broader concept than sovereign risk is, which is restricted to the risk of lending to the government of a sovereign nation. An assessment of the willingness to pay, for example, is one of the distinguishing features of sovereign credit analysis compared to corporate credit analysis. Country risk assessment does not only involve an assessment of willingness of the state to fulfil its obligations, as other factors can also cause losses. In practice, sovereign risk and country risk are highly correlated, however, as the government is the major actor in sovereign and country risk affairs.

Nagy sees transfer risk, defined as the inability of private agents to fulfil their obligations due to government actions, as one of the most important drivers of country risk. One example of transfer risk is when the government has imposed prohibitive exchange restrictions, which may make it impossible for private agents to transfer payments. This type of country risk only applies to private borrowers. If instead the government cannot service its own debt because it does not have the required amount of foreign exchange or is unwilling to service its debts, then these events would be classified as sovereign default, renegotiation, rescheduling or a form of technical default. For the purpose of this paper, we will not take into account of industrial countries where transfer risk can be assumed to be non-existent.

Of course, credit risk involves other forms of country risk as well. Since the East Asian financial crisis, it has become clear that country risk can occur in forms other than transfer risk or sovereign risk. In particular, an overall deterioration of credit risk in the country can lead to many private contracts not being observed, although the government does not impose any specific balance-of-payments restrictions. This credit concentration risk has been called collective debtor risk (or domestic economic risk) and relates to the likelihood that countrywide (political, economical) events occur which negatively influence the quality of a bank's overall portfolio in a country. We do not consider this risk part of transfer risk. 
Another important aspect of measuring country risk arises from the growing openness and interdependence of emerging markets, involving larger dependency on foreign capital. The growing openness - in combination with freer capital accounts and herd behavior by investors - seem to have increased the negative spill over effects from a crisis in one country to other emerging markets. This phenomenon of contagion is very relevant for Economic Capital calculations since higher correlation between changes in asset values implies higher required Economic Capital (see Appendix 1). To the extent this interdependence raises the chances of government actions leading to the inability of private agents to fulfil their obligations, we consider this risk part of transfer risk.

The growing interdependence between countries has also had implications for country risk assessment in other ways. Foreign investors embraced in the 1990s emerging markets that adopted market reforms and consequently the role of the international sector has grown substantially in many emerging markets. Many companies from emerging markets rely now on access to international capital markets for their financing needs. A transfer risk event would jeopardize access of these companies to international capital markets and in turn damage the country's overall economic situation. Governments of emerging markets today therefore have greater incentives than in the past to avoid transfer risk events, as the costs of these events - through exclusion from future borrowing and losses stemming from lower trade and FDI flows-have risen.

In the event of an external shock or another form of crisis, it is therefore much more likely today that a government will choose means other than imposing transfer restrictions to resolve any problems. A government may, for example, first decide to default on its own bonds to alleviate foreign exchange pressures and in order to avoid imposing a blanket debt moratorium on all foreign currency borrowers (including internationally operating companies). External pressures may reinforce this preference. In recent crises in countries like Argentina, Ecuador, Bulgaria, Ukraine, Pakistan, governments may have been encouraged by international donors and the IMF to first default on their sovereign debts in order to have bondholders 'share the burden' of problems. The conclusion that transfer risk may have decreased in certain countries, is not to say that country risk has decreased commensurate. A currency crisis may, for example, still lead to large losses for banks stemming from increased collective debtor risk.

Based on this discussion, we use the following definition of country risk: "the risk of exposure to losses caused by events in the particular country, which may be under the control of the government but not under the control of a private enterprise or individual." Transfer risk and collective debtor risk are important, non-exclusive sub-categories of country risk under this definition. Transfer risk is the risk that the government will impose restrictions on the transfer of funds by debtors in the country in question to foreign creditors, either for financial or other reasons. This risk is almost exclusively related to foreign currency exposure. Collective debtor risk is the risk that countrywide events occur that negatively influence the quality of the bank's portfolio in the country. Finally, sovereign risk is the risk that the government will fail to comply with its 
obligations. In practice, sovereign risk may be highly correlated with country risk, but is still conceptual a different form of risk.

A transfer risk event involves thus an action by the government to impose restrictions to the transfer of funds from the debtors in the country to foreign creditors. Note that apart from a transfer risk event, there are numerous other crises, which can be labeled country risk (e.g., a currency crisis or large scale-banking crisis). These events will most often lead to losses stemming from we call collective debtor risk, but these events do not necessarily lead to a transfer risk event. The Basel II proposals primarily address credit risk, with collective debtor risk assumed to be an integral part of credit risk (and in the correlation of defaults). In all explicit references, country risk in Basel II is restricted to transfer risk. ${ }^{1}$ We therefore restrict our discussion and analysis as well to transfer risk only.

\section{Basel II, Economic Capital and Country Risk}

Basel II allows two approaches to measuring credit risk: the standardized approach and the Internal Ratings Based (IRB) approach. The standardized approach is more or less a refinement of the present Basel I approach. One of the major changes from Basel I is that the OECD/non-OECD distinction will be abandoned and that creditworthiness will be determined by ratings, as set by international rating agencies, export credit agencies or other rating providing entities. ${ }^{2}$ Moreover, the so-called 'sovereign ceiling' will be abandoned in one of the two options of this approach, in the sense that banks and corporations may be assigned a higher rating than their sovereign may.

For lending to sovereigns, OECD countries received a 0\% weight under Basel I system, whereas non-members received a $100 \%$ weight. This rather crude distinction failed to differentiate between the very real differences in sovereign risk between both members and non-members of the OECD and among OECD and non-OECD members. ${ }^{3}$ A more differentiated approach has been proposed based on the ratings of the rating agencies. For bank to bank lending and lending to corporations, similar systems apply,

\footnotetext{
1 On p. 50 of the New Basel Capital Accord, the Basel Committee explicitly includes transfer risk in the list of criteria on risk assessment of a borrower by stating that "the risk characteristics of the country (the borrower) is operating in, and the impact on the borrowers' ability to repay, (including transfer risk) where the borrower is located in another country and may not be able to obtain foreign currency to service its debt obligations." On p. 11 of the Internal Ratings-Based Approach, the Basel Committee states that country (transfer) risk is almost universally considered a risk factor in the rating assignment process for crossborder lending.

2 The latest draft of the Basel II proposal allows for the inclusion of the ratings provided by other entities, such as export credit agencies. This change is a reflection of comments on the earlier consultative paper that the rating agencies' performance has been rather poor in some instances.

3 It has been argued this distinction contributed to making membership of the OECD an overriding goal of some countries. A noted example is South Korea, which removed many controls on capital inflows in the mid-1990s partly to satisfy OECD entry requirements.
} 
although there are two options that can be chosen. The risk weights in Basel II are provided in Table 1.

Table 1. Sovereign creditworthiness Risk Weights

\begin{tabular}{|c|c|c|c|c|c|c|}
\hline Rating & $\begin{array}{c}\text { AAA to } \\
\text { AA- }\end{array}$ & $\begin{array}{c}\mathrm{A}+\text { to } \\
\mathrm{A}-\end{array}$ & $\begin{array}{c}\mathrm{BBB}+\text { to } \\
\mathrm{BBB}-\end{array}$ & $\begin{array}{c}\mathrm{BB}+\text { to } \\
\mathrm{B}-\end{array}$ & $\begin{array}{c}\text { Under } \\
\text { B- }\end{array}$ & $\overline{\text { Unrated }}$ \\
\hline Risk-Weights & $0 \%$ & $20 \%$ & $50 \%$ & $100 \%$ & $150 \%$ & $100 \%$ \\
\hline
\end{tabular}

The second and more refined method, the Internal Ratings Based Approach (IRBA) leaves much more freedom to individual banks to use their 'advanced' internal risk management systems for calculating regulatory capital. Although this has not been explicitly confirmed by the Basel Committee, banks assume that they can use the estimates of default probabilities, loss given default and exposure at default (as used in their internal Economic Capital systems) under this approach (see Appendix 1).

While the Basel Committee does not prescribe in detail how risk should be assessed, the Committee refers to statistical models as an important way to rate credit risk. Banks have interpreted the Basel II proposal as promoting an Economic Capital model with rating models as a correct implementation of the IRB approach proposal. The Committee mentions the following criteria for the use of rating models: the variables used in a model must have statistical power; the model should capture all key variables; and the variables that are not considered in the model should be focussed on risk assessment conducted by expert personnel. ${ }^{4}$

\section{The reliability of sovereign ratings}

As the Basel II uses sovereign ratings as a tool for determining overall risk in the standardized approach, reliability of ratings is a very important condition. Reliability of ratings can be tested in various ways. We focus in this section on the market responses to announcements of rating or outlook changes and the stability of ratings, although there are other ways to test the reliability of ratings, including analyzing their determinants (section 4).

\section{Announcement effects and effects on spreads}

The easiest way to measure the impact rating agencies have on the financial markets is to test for causality from ratings to spreads. Most of the research on the influence of credit ratings on bond prices has been done in the field of corporate bonds, equities and commercial paper. These studies have often focused on the issue of whether changes in ratings convey information not already incorporated into prices. While the empirical results are not uniform, they typically find that there is a more significant effect from a downgrade rather than from an upgrade and that the largest effect is there when the rating change is 'unexpected.'

\footnotetext{
4 See Basle Committee (2001), Consultative Document, p. 51, paragraph no. 266.
} 
For sovereign ratings, the results are more mixed. Cantor and Packer $(1995,1996)$ studied the effects of rating announcements by S\&P and Moody's on 'relative spreads,' i.e., the differential between yields on sovereign dollar-denominated eurobonds and on comparable U.S. treasury, using data from 1987 until 1994. The conclusions of this event study were as follows. Announcements of a change in sovereign risk assessment appear to be preceded by a similar change in the markets' assessment. In the 29 days preceding negative respectively positive announcements, relative spreads rose cumulative 3.3 respectively declined 2.0 percentage points. This trend disappears shortly before the announcements. After the announcement, statistically significant bond yield movements in the expected direction followed positive announcements in the agencies' ratings, but negative changes did not produce significant effects. Rating announcements also have a highly significant impact on spreads of speculative grade sovereign bonds but not for investment-grade sovereign bonds, with an announcement by Moody's having a higher impact than announcements by S\&P.

Larrain, Reisen and von Maltzan (1997) and Reisen and von Maltzan (1999) replicated the method of Cantor and Packer closely to study the impact of rating announcements by Moody's, S\&P and Fitch IBCA..$^{5}$ They also employed a larger (and more recent) sample period, from 1989 to 1997. Reisen and von Maltzan question the results by Cantor and Packer. They find that the impact of one rating announcement is not significant for all countries in the sample period. A significant change in the yield spread in the expected direction occurred during the announcement period only when a downgrade was implemented. These results contrast those of Cantor and Packer, who found significant effects only for positive announcements. One similarity between the two studies is that Reisen and von Maltzan find that the largest announcement effects are for emerging market sovereign spreads. As noted above, Cantor and Packer found the largest effects for speculative grade bonds, which more or less correspond to those issued by emerging market sovereigns. Moreover, Reisen and von Maltzan also find that a rise in yield precedes a downgrade. Apart from a replication of the Cantor and Packer test, Reisen and von Maltzan also do a Granger causality test to examine the interaction between spreads on sovereign bonds and credit ratings, after allowing for the influence of macroeconomic country risk determinants. The authors conclude that the three leading credit ratings agencies do not independently lead the market and that there is a two-way causality between ratings and spreads.

In general, this research suggests that the rating agencies do not so much lead but lag the market and the rating agencies are overall slow to adjust their ratings. Moreover, the findings of Cantor and Packer and Reisen and von Maltzan suggest that the criticism on the rating agencies in the wake of the Mexican and the Asian crisis may also apply to a longer period as well. These findings are confirmed by recent work by Kaminsky and Schmukler (2002) who conclude not only that rating agencies contribute to financial instability and cross-country contagion, but also confirm that rating agencies act procyclical.

${ }^{5}$ For a more recent study of announcements effects, see Kaminsky and Schmukler, 2002. 


\section{Rating stability and actual defaults}

Corporate ratings are fairly stable, also over the business cycle, and provide a reasonable measure of the relative chances of a corporation's default (Altman and Saunders, 1998). On the basis of an overview of sovereign ratings in the twentieth century, the IMF (1999) concludes that sovereign ratings have a more 'checkered' history than corporate ratings. Most sovereign ratings were lowered during the 1930s Great Depression, with 21 out of 58 nations defaulting on their international bonds between 1930 and 1935 . On a volume basis, roughly $70 \%$ of all sovereign debt (excluding Canadian debt) issued in the US between 1926 and 1929 defaulted before the end of 1937, compared to a US corporate bond default figure of $30 \%$.

After World War II the picture is less clear. S\&P (1998) found that 30 out of the 72 governments at least once defaulted on their domestic or foreign currency debt since 1970. In examining the experience with sovereign ratings for emerging markets in the late 1990s, however, sovereign ratings have been much more stable until the Asian and Russian crisis (see Figure 1; see also Caouette et al. (1998), p. 72-74). If the figures of 1998 are compared with 1997, the number of single B rated countries increases at the expense of higher-rated countries. ${ }^{6}$

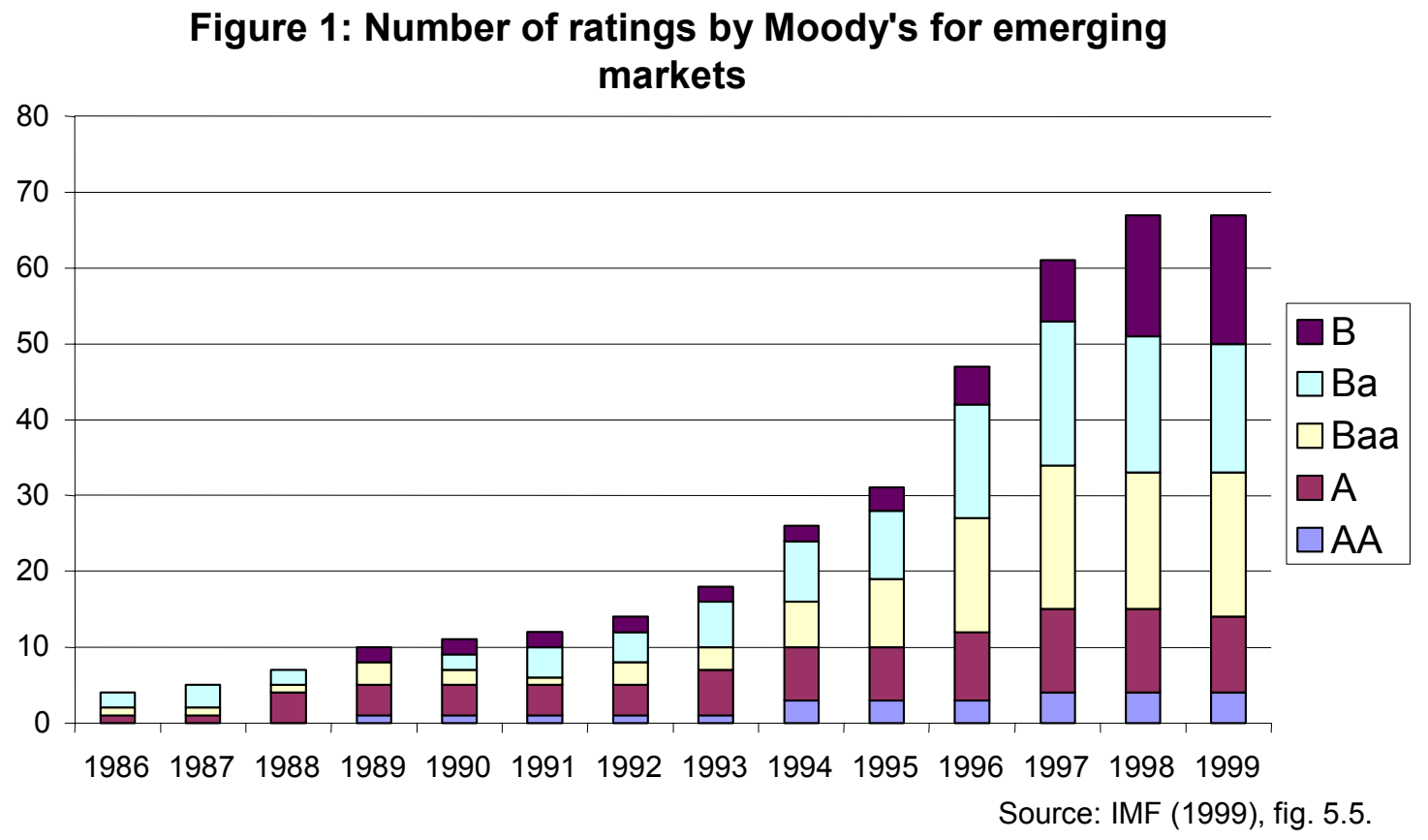

The lower average of sovereign ratings is, however, not matched by a higher number of sovereign defaults in the late 1990s. As can be seen from Figure 2, the number of new

\footnotetext{
6 For this comparison, it should be noted that not all newly rated emerging markets in 1998 received a rating B. See IMF (1999), ch. 5.
} 
sovereign defaults reached an all-time high in 1983, but declined afterwards.

After 1992, the number of sovereign defaults has been very low. S\&P has noted that defaults by sovereign issuers of bank and bond debt have declined in recent years, until Russia (1998/1999) and Ecuador (2000) failed to honor obligations (Standard and Poor's, 1998). In addition Indonesia, Pakistan and Russia have defaulted on non-rated paper in foreign currency since 1998.

Figure 2: Number of New Sovereigns in Default

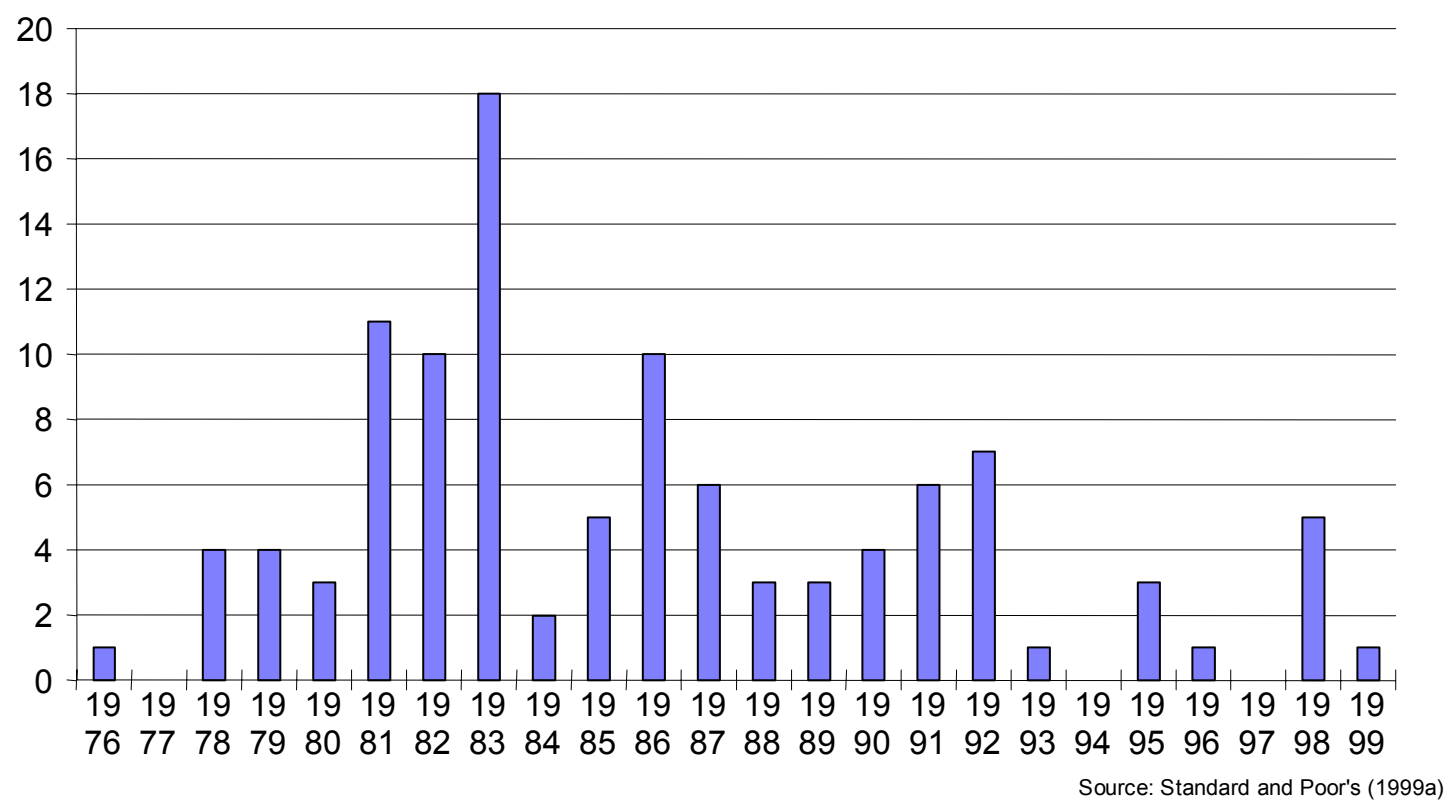

The level of sovereign and bank ratings for the East Asian countries prior to the Asian crisis and the behavior of the rating agencies during the crisis have received a lot of attention. It is generally concluded that the rating agencies failed to predict this crisis and critics argue that the subsequent downgrades during the crisis were a clear case of overreaction and contributed to the intensity of the crisis (Huhne, 1998). However, prior to the outbreak of the crisis, the same agencies had been accused of being too conservative. After the Asian crisis, all major rating agencies have reviewed their rating process. The most important changes are greater emphasis on the risks of short-term debt for otherwise creditworthy countries, a greater emphasis of the systemic risks in a (weak) banking sector and greater appreciation for vulnerability to liquidity crises and contagion (see Fitch IBCA, 1998, and IMF, 1999).

Overall, it is rather paradoxical that the rating agencies have substantially downgraded emerging markets' bonds in the late 1990s, while this was not matched by a larger number of defaults. In the more distant past sovereign risk has been higher than often assessed by the rating agencies, banks and other market participants. This can mean two things. First, this may imply that the present 'low sovereign default situation' is a temporary deviation for a longer trend. A second conclusion may be that sovereign risk and transfer risks in general have decreased, but this has not yet been fully reflected in 
the ratings. Instead, the rating agencies may have overreacted in the wake of the Asian 'ratings crisis'.

\section{Rating determinants}

In this section, we review the empirical literature on the determinants of sovereign ratings and provide the regression results of the most commonly used model. We also analyze the ratings of transfer risk for a major international bank, and compare these determinants to those of sovereign ratings.

\subsection{Sovereign ratings}

Cantor and Packer (1996) examined the determinants of the levels of Moody's and S\&P ratings for 49 mature and emerging market economies as of 29 September 1995. After converting these ratings to a numerical scale (with the highest Aaa/AAA $=16$ and the lowest $\mathrm{B} 3 / \mathrm{B}-=1$ ), they regressed these ratings on a set of economic variables that had been identified by the agencies as influencing the level of a sovereign's rating. As we will be using the same set of variables, we replicate heir definition here (Table 2).

\section{Table 2: Description of variables used by Cantor and Packer (1996)}

\begin{tabular}{ll} 
Per capita income & GNP per capita in 1994 \\
GDP growth & Average annual real GDP (1991-1994) \\
Inflation & Average annual CPI 1992-1994 \\
Fiscal balance & Average central government budget surplus (\% GDP) 1992-1994 \\
External balance & Average current account surplus (\% GDP) 1992-1994 \\
External debt & Foreign currency debt relative to exports 1994 \\
Indicator for economic & IMF classification as an industrialized (country dummy) \\
development & \\
Indicator for default history & $\begin{array}{l}\text { Default on foreign currency debt since 1970 as reported by } \\
\text { S\&P(dummy) }\end{array}$ \\
\hline
\end{tabular}

Source: Cantor and Packer (1996), table 3.

The reference date of most of the explanatory variables was rather arbitrary. For some variables, a reference value of 1994 was taken, for others an average value of 19911994 or 1992-1994. No forecasts were taken into account. Appendix 2, Table 1 provides the regression results of the Cantor and Packer analysis.

The results were impressive in terms of explanatory power. On average the variables explain $92.4 \%$ of the cross-country variation in ratings, with the explanatory power for S\&P being slightly higher than for Moody's, but otherwise very little differences between the two rating agencies. The individual country prediction is consequently very good, with a standard error of only 1.2 notches in ratings. The regression does not lead to any errors exceeding 3 notches in ratings and on average the rating regression predicts broad letter ratings (A, B, etc.) with about $70 \%$ accuracy. 
Cantor and Packer add, however, that the regression achieves its high $\mathrm{R}^{2}$ through its ability to explain large differences in rating. The model has little to say about small differences in ratings.

Looking at the separate explanatory variables, the Cantor and Packer results indicate that higher ratings were associated with high per capita income, high GDPgrowth, low inflation, a low ratio of foreign currency external debt to exports, the absence of a history of defaults on foreign currency debt since 1970, and a high level of economic development (as measured by the IMF classification as an industrial country). The coefficients on the fiscal position and the external balance were not statistically significant. ${ }^{7}$

Jüttner and McCarthy (1998) looked into whether the Cantor and Packer results also held for the turbulent period of the Asian 'rating crisis.' 8 First, they re-estimated the regression for 29 September 1995, end-1996, end-1997 and end-1998, with slightly different explanatory variables. ${ }^{9}$ As expected the results were more or less comparable for 1995, 1996 and 1997 but the relationship broke down in 1998 in the wake of the Asian crisis. Jüttner and McCarthy also constructed a new model, with 'old' (in the 1998 regression) significant variables and new variables for the interest rate differential, financial sector problems and the real exchange rate. All variables except economic development and real exchange rate then became significant at 1\%-level. Although the findings of Jüttner and McCarthy were very relevant for the period of the Asian crisis, it should be noted that their analysis tried to find ex post explanations for the ratings behavior in one particular 'crisis' year and as such can amount to data-snooping.

\subsection{Determinants of transfer risk ratings}

To conduct a formal comparison between the determinants of sovereign ratings by external rating agencies and internal transfer ratings by financial institutions, transfer risk ratings used at an international bank were used. Ratings as of April 2000 are taken for 63 developing countries and emerging markets. ${ }^{10}$ It is important to note that this sample does not include many industrial countries.

For transfer ratings, a scale of 1 to 7 was used, with 1 indicating the highest risk. All data for the explanatory variables come from the EIU (EIU Country Data April 2001),

\footnotetext{
7 The authors explain the lack of clear correlation between ratings and fiscal and external balances by the endogeneity in both fiscal policy and international capital flows: a country that tries to enhance its credit rating, will opt for a more conservative fiscal policy. In addition, the indicators for budget deficit and current account deficit may not reveal the most relevant information on the sustainability of external or fiscal situation. A deteriorating trend may in that respect be more relevant. Moreover, as supply of capital to low rated countries will be limited, the build up of foreign debt will be less.

8 A ratings crisis is defined by the authors as a three-notch sovereign credit rating downgrade on long-term foreign currency debt over any six-month period.

${ }^{9}$ Among other differences, they used three-year averages instead of two-year averages for some variables.

10 See Appendix 2 for the countries included in the sample. As we focus on transfer risk, G-10 countries, other countries of the European Economic Association, Australia and New Zealand are excluded.
} 
except when stated otherwise. In line with Cantor and Packer, the predictive power of several indicators is explored. In particular, we use the following variables: Per capita income, measured by GDP per capita; Economic growth, measured as the average GDP growth from 1998-2000; Inflation: measured as the average rise in CPI in 1998-2000; Fiscal balance, measured by the average budget surplus/deficit (as a \% of GDP) in 19982000; External balance, measured by the balance on the current account (as a \% of GDP) in 1998-2000; Indicator for economic development: IMF classification as an industrialized country in 2000; and Indicator for default history: default on debt rated by S\&P or agreement at the Paris club in the period 1980-2000.

The results of the first regression are comparable to the regression by Cantor and Packer and are presented as Regression 1 in Table 3. All variables have the expected sign, except for Fiscal Balance. The statistical insignificance of Fiscal Balance and External Balance is in line with the findings of Cantor and Packer.

\begin{tabular}{|l|c|c|c|c|}
\hline \multicolumn{4}{|c|}{ Table 3: Determinants of transfer rating } \\
\hline \multicolumn{1}{|c|}{ Explanatory Variable } & \multicolumn{2}{|c|}{ Regression 1 } & \multicolumn{2}{c|}{ Regression 2 } \\
\hline & Parameter & t-stat. & Parameter & t-stat. \\
\hline Intercept & -4.279 & -1.392 & -1.000 & -0.315 \\
Per capita income & 1.332 & 4.458 & 0.992 & 3.133 \\
GDP growth & 0.449 & 2.893 & 0.313 & 1.986 \\
Inflation & -0.306 & -1.162 & -0.176 & -0.695 \\
Fiscal balance & -0.069 & -0.785 & -0.021 & -0.246 \\
External balance & 0.021 & 0.411 & 0.016 & 0.344 \\
External debt & -0.007 & -2.059 & -0.007 & -2.067 \\
Ec. Development & 3.681 & 3.585 & 4.188 & 4.360 \\
Default history & -0.236 & -0.326 & & \\
Default history (95-00) & & & -1.908 & -2.368 \\
\hline Adj. ${ }^{2}$ and std error & 0.726 & 2.06 & 0.753 & 1.96 \\
\hline
\end{tabular}

The fact that inflation and default history are not significant differs from the findings of Cantor and Packer. The lower significance of inflation may be explained by the fact that the sample is restricted to data for emerging markets (where inflation is generally higher). For default history, the insignificance maybe because the value for the dummy for default in the research by Cantor and Packer is actually determined by a rating of S\&P ('D', or selective default), while this is not the case for the transfer rating. A second explanation may be that different sources were used. Cantor and Packer used S\&P data for default history to explain S\&P ratings, which are not independent of the ratings themselves. For transfer ratings, actual default data were used that were fully independent of the transfer ratings. To further test our specification, we adjust the definition of the default variable. Since it can generally be expected that a default 20 years ago will not have the same impact on a rating than a default 5 years ago, the period for the default history was shortened from 1980-2000 to 1995-2000. Default history was now significant but inflation is still not significant (see Table 3, column 4 and 5). 
The predictive power of the model $\left(\mathrm{R}^{2}=72.6 \%\right)$ is much lower than that of Cantor and Packer $\left(\mathrm{R}^{2}=92.4 \%\right)$, but this can be explained by the fact that the transfer rating sample is restricted to emerging markets. The explanatory power of GDP per capita and the dummy for industrial country can thus be expected to be lower. It also reflects that this specification is not subject to the critique of data-snooping since we use their specification directly, rather than trying to find a set of explanatory variables with the highest predictive power.

\subsection{Comparison of sovereign rating and transfer rating models}

Although the regression results so far (Table 3) provide some measure of the explanatory power of a model for the ratings from external agencies vis-à-vis the explanatory power of a similar model for internal, transfer ratings, the actual parameters of the two rating regressions cannot be directly compared since the sample used is different. We therefore re-estimated the internal rating and the Cantor and Packer model for the same sample and using an unweighted average of Moody's and S\&P ratings as of April 6 2001. Twelve countries have a transfer rating but no rating by both Moody's and S\&P and these have therefore been excluded from both regressions. These are mostly countries with a low GDP per capita. The results for both regressions are displayed in Table 4.

The prediction power of the regressions for transfer rating and for the average Moody's and S\&P rating are similar as before, both about 75\%. External Balance and Fiscal Balance are not significant, in line with the Cantor and Packer findings in 1995. However, the variables for External Debt and Inflation are not significant as well.

\begin{tabular}{|c|c|c|c|c|c|}
\hline \multirow[t]{2}{*}{$\begin{array}{c}\text { Explanatory } \\
\text { Variable } \\
\end{array}$} & \multicolumn{2}{|c|}{ Transfer rating } & \multicolumn{2}{|c|}{$\begin{array}{c}\text { Average S\&P and } \\
\text { Moody's }\end{array}$} & \multirow{2}{*}{$\begin{array}{c}\text { Wald test } \\
\text { p-value } \\
\end{array}$} \\
\hline & Parameter & t-stat. & Parameter & t-stat. & \\
\hline Intercept & 0.510 & 0.736 & -0.045 & -0.009 & 0.61 \\
\hline Per cap. income & 0.637 & 1.341 & 1.249 & 2.342 & 0.39 \\
\hline GDP growth & 0.478 & 2.722 & 0.508 & 2.577 & 0.91 \\
\hline Inflation & -0.287 & -0.740 & -0.270 & -0.619 & 0.98 \\
\hline Fiscal balance & 0.360 & 1.824 & 0.315 & 1.420 & 0.88 \\
\hline External balance & -0.030 & -0.487 & -0.054 & -0.778 & 0.80 \\
\hline External debt & -0.006 & -1.207 & -0.004 & -0.697 & 0.78 \\
\hline Ec. Development & 3.400 & 2.602 & 1.881 & 1.281 & 0.44 \\
\hline Default history & -0.998 & -1.038 & -2.178 & -2.015 & 0.42 \\
\hline $\begin{array}{l}\text { Adj. } R^{2} \text { and std } \\
\text { error }\end{array}$ & 0.759 & 1.96 & 0.742 & 2.20 & \\
\hline
\end{tabular}

To compare the values of the parameters statistically, a Wald test was performed (column 5), with p-values that the two parameters are the same given in $6^{\text {th }}$ column. The hypothesis that the parameters are the same can easily be rejected for Per Capita Income, 
Economic Development, Default History and the intercept. The impact of Per Capita Income is larger at the rating agencies, while the parameter for Economic Development is higher for transfer ratings. As these two variables have a positive correlation, the effect of lower weighting for the Economic Development dummy in the rating agencies regression may be compensated by the effect of higher weighting for Per Capita Income in the same regression and vice versa. Transfer rating analysts, however, do regard Default History to be less important than analysts at the rating agencies seem to do. But otherwise, external rating agencies seems to use (implicitly or explicitly) a similar model as the internal ratings imply.

\section{Rating migration behavior}

While it is important to investigate the determinants of the rating levels, to calculate expected default frequencies (EDFs) for Economic Capital or regulatory capital purposes rating migration is at least as important. As a first step, the conclusions of the rating agencies on their research of rating migration will be discussed. Secondly, rating migration matrices for the transfer ratings will be calibrated.

\subsection{Rating migration and default at the rating agencies}

Empirical analyses by the rating agencies can be expected to correlate credit quality and default rates. It is difficult, however, to come up with the default probabilities for sovereign ratings for two reasons. First, there has only been a limited experience with sovereign ratings, both in terms of the length of time since the ratings began (for most emerging market countries only the early 1990s or later) and the number of countries that has been rated. Second, under the definitions of default employed by the agencies, there were only four defaults on foreign-currency-denominated debt rated by rating agencies. ${ }^{11}$ Therefore, the relationship between ratings and default probabilities and the related migration of ratings to lower, default categories may be tenuous for sovereign ratings. More relevant may be the findings of the corporate credit rating migration, which will therefore be discussed first. Since S\&P has - in spite of the above-mentioned caveats — calibrated a sovereign rating migration index, their findings will be discussed as well.

\section{Corporate credit rating migration by Moody's}

Most attention has been paid to calculate corporate credit rating migration. These studies generally confirm that the default probability of an AAA-rated entity is lower than an AA-rated entity, which is in turn lower than for an A-rated company etc. The rating agencies argue that ratings reflect relative default probabilities and see the absolute level of the default risk as being influenced by the state of the business and credit cycles. The default probabilities are therefore period dependent (with higher concentration of defaults in periods of economic depression). Absolute default probabilities may, however, not be inferred from the credit rating categories as default. For a good

11 Indonesia (twice), Pakistan and Russia. 
understanding of the migration matrices of the rating agencies, it is also important to note that rating migration at the rating agencies is calculated by comparing the ratings at the beginning of the year with the ratings at the end of the year.

A study by Moody's (2001) showed the to be expected inverse relationship between default rates and rating categories, with a clear pattern of higher risk of default for the speculative grade rating categories (Table 5). The only exception is the default probability of AA-rated corporations of $0.03 \%$, which can be compared to a $0.01 \%$ probability for A-rates corporations. Moody's notes that this relatively high risk and exception to the monotonic increase in default risk as ratings decline may fall under the umbrella of 'event risk'. Moreover, there is different rating behavior regarding Caa-C rated companies. The study also showed that the volatility of default rates increases with lower credit rating. The lower predictability of default rates may explain the significantly higher risk premia required by investors in lower-rated issues.

Table 5: One year migration matrix of Moody's corporate ratings (1980-2000, percent)

\begin{tabular}{lccccccccc}
\hline Rating to: & Aaa & Aa & A & Baa & Ba & B & Caa-C & Default & WR* \\
Aaa & $\mathbf{8 6 . 1 7}$ & 9.45 & 1.02 & 0.00 & 0.03 & 0.00 & 0.00 & 0.00 & 3.33 \\
Aa & 1.10 & $\mathbf{8 6 . 0 5}$ & 8.93 & 0.31 & 0.11 & 0.01 & 0.00 & 0.03 & 3.46 \\
A & 0.06 & 2.85 & $\mathbf{8 6 . 7 5}$ & 5.58 & 0.66 & 0.17 & 0.01 & 0.01 & 3.91 \\
Baa & 0.06 & 0.34 & 6.64 & $\mathbf{8 1 . 0 0}$ & 5.52 & 0.97 & 0.08 & 0.16 & 5.23 \\
Ba & 0.03 & 0.06 & 0.54 & 5.46 & $\mathbf{7 5 . 5 0}$ & 8.18 & 0.53 & 1.32 & 8.38 \\
B & 0.01 & 0.04 & 0.20 & 0.56 & 5.92 & $\mathbf{7 5 . 9 4}$ & 3.03 & 6.41 & 7.90 \\
Caa-C & 0.00 & 0.00 & 0.00 & 0.87 & 2.61 & 5.62 & $\mathbf{5 7 . 0 2}$ & 25.31 & 8.58 \\
\hline
\end{tabular}

Source: Moody's (2001), exhibit. 36, p. 44. ${ }^{*} \mathrm{WR}=$ withdrawn rating

A valid question remains whether corporate credit rating migration can be compared with sovereign rating migration. Moody's has stated that on the basis of rating behavior over time, default rates for sovereign issuers should broadly parallel the corporate default rates. Standard \& Poor's expects sovereign rating stability and default probability to converge over time with the behavior for corporate ratings as the number of sovereign rating observations increases (Standard and Poor's, 2000). There are, however, some indications, that this presumption by the rating agencies may not hold. Cantor and Packer find that sovereign bonds rated below A tend to be associated with higher spreads than comparably rated US corporate securities. They interpret this finding as more pessimism by markets on sovereign credit risks than the ratings analysis of S\&P and Moody's implied. This could point in the direction that markets do not support a one to one calibration of corporate credit ratings into sovereign ratings.

\section{Sovereign rating migration by $S \& P$ ratings}

On the basis of a rather small sample of sovereign ratings (due to a lack of ratings for emerging markets in the 1980s), S\&P (2000) has calculated a sovereign rating migration matrix (Table 6). S\&P notes that comparisons between sovereign and corporate default rates are skewed by the small sample size of sovereign defaults. 
Table 6: One year migration matrix of S\&P sovereign foreign currency ratings (1975-1999, percent)

\begin{tabular}{|c|ccc|ccc|c|c|}
\hline Rating to & AAA & AA & A & BBB & BB & B & CCC & SD or D \\
\hline AAA & $\mathbf{9 7 . 4 5}$ & 2.55 & 0 & 0 & 0 & 0 & 0 & $\mathbf{0}$ \\
AA & 0.71 & $\mathbf{9 7 . 1 4}$ & 0.71 & 0 & 0.71 & 0.71 & 0 & $\mathbf{0}$ \\
A & 0 & 4.05 & $\mathbf{9 3 . 2 4}$ & 2.7 & 0 & 0 & 0 & $\mathbf{0}$ \\
\hline BBB & 0 & 0 & 5.33 & $\mathbf{8 8 . 0 0}$ & 5.33 & 1.33 & 0 & $\mathbf{0}$ \\
BB & 0 & 0 & 0 & 7.06 & $\mathbf{8 3 . 5 3}$ & 7.06 & 0 & $\mathbf{2 . 3 5}$ \\
B & 0 & 0 & 0 & 0 & 14.81 & $\mathbf{8 1 . 4 8}$ & 0 & $\mathbf{3 . 7}$ \\
\hline CCC & 0 & 0 & 0 & 0 & 0 & 0 & $\mathbf{0}$ & $\mathbf{0}$ \\
SD or D & 0 & 0 & 0 & 0 & 0 & 33.33 & 33.33 & $\mathbf{3 3 . 3 3}$ \\
\hline
\end{tabular}

Source: S\&P (2000), Sovereign Ratings History Since 1975

$\mathrm{SD}$ is selective default; $\mathrm{D}$ is default.

A first finding from the migration matrix is that sovereign ratings show larger stability as one ascends through the rating scale in line with credit ratings. The balance between upgrades and downgrades is more or less even and compared with corporate ratings, sovereign ratings show slightly more stability. Despite the overall relative stability of the sovereign ratings, however, some sovereigns suffered sharp downgrades during the recent crises. ${ }^{12}$ Moreover, in all categories of ' $\mathrm{A}$ ' the sovereign default record has been lower than the corporate default record, while it has generally been higher for speculative grade issuers. A second finding from the migration matrix is that there is one abnormal migration of ratings in the higher categories. The probability that sovereigns rated AA by $\mathrm{S} \& \mathrm{P}$ will be downgraded in one year to $\mathrm{BB}$ or $\mathrm{B}(1.42)$ is much higher than the probability of a downgrade to BBB (0.00). A third general finding, which can not be deducted from the rating migration matrix but has been found by Altman and Saunders (1998), is that a downward adjustment of a rating is followed relatively frequently by further downward adjustments. However, after an upgrade the chance of a further upgrade is just as great as a downward adjustment. Altman and Saunders conclude from this that agencies only downgrade ratings in small steps in order not to hurt their relationships with the issuer, who is after all ultimately their client, with a single downgrade. Another frequently heard argument for the reluctance to downgrade is the agencies' fear of sparking a crisis.

\subsection{Migration matrices for transfer risk ratings}

To calculate rating similar migration matrixes and EDFs for the internal ratings, it is important to use a practically applicable definition of transfer risk default event. The general definition of a transfer risk event in section 1 can not be used, as it is often impossible to distinguish default for reasons of transfer risk from corporate default. As our sample of internal ratings is restricted to transfer risk ratings, the events of default are assumed to be equal to receiving the lowest rating in the transfer risk system, being a

12 Indonesia, Thailand, Korea, Malaysia and later Romania, Russia and Venezuela were all downgraded by more than three levels within six months. See further Jüttner and McCarthy (1998). 
rating of 1 . This is consistent with practices in the past since in case of a sovereign default or a transfer risk event, the internal rating was downgraded to 1 .

Transfer ratings are available for 1990 - 2001, which is a similar period as sovereign ratings are available, but the transfer ratings cover a wider set of countries. Ratings were generally given at fixed time periods (e.g., in February, April and June, September and December). Since the intervals between subsequent ratings are not equal, all rating changes were adjusted to an annual basis. If the changes in ratings only cover a period of two months (e.g., from February to April), the migration matrix was multiplied six times, to come to the appropriate maturity of twelve months. Rating changes between say June to September and September to December were multiplied only four times, as the time between these ratings is three months. The weighted sum of all migration matrices constitutes the final migration matrix, with a maturity of one year. The main advantage of proceeding in this way is that information of any intra-period migration is also included in the matrix. The results are depicted in Table 7.

\begin{tabular}{|c|c|c|c|c|c|c|c|c|}
\hline \multicolumn{9}{|c|}{$\begin{array}{l}\text { Table 7: Migration matrix for internal transfer ratings } \\
\qquad(1990-2001 \text {, percent })\end{array}$} \\
\hline & & & 6 & & & & & 1 \\
\hline 7 & 100.0 & 0 & 0 & 0 & 0 & 0 & 0 & \\
\hline 6 & 4.5 & 89.4 & 5.2 & 0.6 & 0 & 0.3 & 0 & \\
\hline 5 & 0.2 & 4.0 & 82.3 & 10.5 & 0.3 & 0.8 & 2.0 & \\
\hline 4 & 0 & 1.1 & 8.4 & 81.9 & 6.2 & 1.7 & 0.7 & \\
\hline 3 & 0 & 0 & 0.2 & 5.5 & 83.6 & 9.5 & 1.2 & \\
\hline 2 & 0 & 0 & 0 & 0.5 & 17.8 & 75.7 & 5.9 & \\
\hline 1 & 0 & 0 & 0 & 0.2 & 6.7 & 14.3 & 78.8 & \\
\hline
\end{tabular}

Overall, results are in line with our expectations, with monotonic relationships between probabilities of downgrades as grading levels. The exception is the downward migration (to 1 ) of category 5 , with a probability of 2.0 percent. Looking in more detail at the sample, it becomes clear that four countries are responsible for the relatively high migration probability of category 5 countries to the default category: Malaysia (1998, Asian crisis), South Korea (1998, Asian crisis), Kuwait (1990, Gulf war) and Russia (1991, split up of the Soviet Union). It is interesting to note that three of these four events had a high (unexpected, at least not forecasted) political component.

\subsection{Comparing transfer rating migration with $S \& P .13$}

It is interesting to compare the transfer rating migration matrix results with the results of the S\&P. To make a numerical comparison, one adjustment has to be made, since S\&P ratings are divided into eight categories and transfer ratings into seven. From a

13 As the sovereign rating migration matrix by S\&P deals with a period from 1975-1999, we also compared the transfer rating migration matrix for 1990-2001 with the transfer rating migration matrix for 1980-2001. The differences are not substantial. 
comparison between transfer rating and S\&P rating definitions, it appears that a transfer rating of 1 can be compared to a rating $\mathrm{CCC}$ or lower. Therefore, the S\&P rating categories CCC and SD or D are cumulated. As the sample of countries initially rated CCC by S\&P is very small and no country has had a rating CCC in the period 1975-1999 at the beginning of the year, the loss of information of reducing the S\&P categories from eight to seven is very small.

The comparison shows that rating stability is slightly higher for the S\&P sovereign ratings than for the transfer ratings in the higher categories. Two explanations come to mind. First, the S\&P migration index includes both industrialized and nonindustrialized countries, whereas the internal transfer rating sample includes only nonindustrialized countries. As explained in section 4.1, rating migration of lower rated entities is higher than for higher rated entities. A second explanation may be the different way of calculating the migration matrix. Implied default probabilities for the lower categories are higher when using the transfer risk ratings than using the S\&P ratings. This may be explained by the broader definition of default (rating 1) by the international bank than by S\&P. On average, only about $20 \%$ of the international bank 'transfer events' are also sovereign defaults registered by $\mathrm{S} \& \mathrm{P}$.

The most important finding, however, is that the S\&P sovereign rating migration matrix, the international bank transfer rating migration matrix and to a lesser extent the Moody's corporate rating migration matrix, all have one abnormal migration of ratings in the higher categories. The probability that sovereigns rated AA by S\&P will be downgraded in one year to $\mathrm{BB}$ or $\mathrm{B}$ is higher than the probability of a downgrade from $\mathrm{AA}$ to $\mathrm{BBB}$. For the international bank transfer ratings, this is the case for rating category 5. Sharp downgrades after unexpected events (often related to 'unwillingness to pay' by the government) appear to explain this abnormal migration behavior.

If the pattern of these sharp downgrades is examined in more detail, S\&P and Moody's do not downgrade countries immediately, but preferred instead a step by step approach. ${ }^{14}$ This fits the conclusions of Altman and Saunders (1998) whom concluded that a downward adjustment of the credit rating is followed relatively frequently by further downward adjustments, but after an upgrade the chance of a further upgrade is just as great as a downward adjustment. By contrast, the downgrades in transfer ratings were much larger and had a one off character. This suggests that internal ratings do not suffer from the same biases as rating agencies do, i.e., they do not cushion the impact by adjusting rates slowly.

\footnotetext{
14 Venezuela from AA to A- on February 11, 1983 and to BB on March 28, 1983. Moreover, South Korea was downgraded from AA- to A+ on October 24, 1997, from A+ to A- on November 25, 1997, from A- to BBB- on December 11, 1997 and from BBB- to B+ on December 22, 1997.
} 


\section{Conclusion}

A first conclusion of our analysis is that the concept of country risk has changed in the 1990s. While transfer risk was the major source of country risk in the 1980s, the growing openness of emerging and the growing interdependence of emerging markets have changed the concept of country risk for banks in two ways. First, the probability of a transfer event happening has become lower, due to higher costs of a transfer event in the form of exclusion of foreign borrowing, losses from FDI and trade flows. Second, even without a transfer event happening, losses stemming from country risk for banks may be high. Collective debtor risk and contagion may lead to substantial losses on the credit portfolio in the event of a large country risk (or regional) crisis. A higher correlation between changes in asset values may imply higher Economic Capital and regulatory capital. This conclusion is very relevant for the new Basel II proposals. Since in the Basel II proposals only transfer risk is explicitly mentioned, it remains an open question how and where the growing importance of collective debtor risk should be dealt with.

A second conclusion is that although country risk analysts and analysts at the rating agencies do not have specific models to assign transfer and sovereign ratings, models can explain rating levels quite well. As the Basel Committee requires these models to have statistical power and to be consistent, it seems that this condition is met. This links in to the question whether the ways in which sovereign risk and transfer risk are rated can be compared. On the basis of the information that both the rating agencies and the international bank provide, one would be tempted to conclude that differences in rating methodology are minor. Both types of risk seem to have the same determinants. However, there are also important differences between the way sovereign risk and transfer risk are rated. Transfer rating changes in cases of adverse developments are large and changes have a one off character. This contrasts with the step-by-step approach by the rating agencies: downward adjustments are relatively often followed by further downward adjustments. Moreover, the rating agencies lag the market. It has been concluded that these small downgrades take place in order not to damage the issuer with a single blow. For Economic Capital calculation purposes, a 'one off' downgrade is preferable to the approach by the rating agencies. The step by step approach by the rating agencies is particularly relevant for the evaluation of the use of the standardized approach of the Basel II proposals.

Regarding rating migration, it is striking to see that credit, sovereign and transfer ratings both have abnormal migration in one of the higher rating categories. This exception is the more interesting as most of the cases behind the abnormal migration of sovereign ratings and transfer risk ratings are cases of 'unwillingness to pay'. In the literature it has been concluded that the 'unwillingness to pay' is the more challenging and the most difficult ingredient of country and sovereign risk assessment, both for the rating agencies and the country risk analysts. One could argue, in line with the label 'event risk' as provided by Moody's, that the exposure to this risk should be tested in a separate way. 
The analysis also points towards suggestions for further research. First, the data used here would allow one to explore the possible procyclical behavior of internal models in the context of country ratings. As mentioned, recent papers have argued that rating agencies may contribute to the instability of emerging financial markets, both directly by affecting stock and bond market returns of the countries being rated and indirectly through cross-country contagion. The analysis here has highlighted that there may be differences between rating agencies and international banks in their adjustments of country risk assessment following the onset of a financial crisis. This raises the question whether international banks may also act differently from general international financial markets towards emerging markets in crises and other emerging markets, thereby contribute differently to financial instability and possible contagion. The data available here would allow this question to be explored.

Second, the data allows one to test theories regarding the relationship between ratings and pricing of sovereign claims. One of the assumption underlying Basel II is that the internal and external ratings bear a relationship to credit risk which in turn is reflected in spreads demanded. Although, as noted, there is a relationship between changes in ratings and spreads, the extent to which external ratings help explain the level of spreads is being debated. The internal ratings data would allow for a comparison on how an international bank's risk assessment relates to spreads and whether this relationship differs systematically from that of external ratings. Furthermore, the times series on internal ratings can help clarify the relationships between risk assessments and actual defaults. In case of pricing country risks, models often use the assumption that default leads to a full loss. In practice, default is not a full loss, but rather a shift tot he left in the distribution of recoverable amounts and often an increase in uncertainty. The low frequency of defaults makes normally for difficult modeling, but using the long time series available for internal ratings can perhaps help in exploring the relationship between spreads, ratings and actual default experiences. 


\section{References}

Altman E.I., and A. Saunders (1998), Credit Risk Measurement: Developments over the last 20 years, Journal of Banking and Finance.

Basel Committee on Banking Supervision (2001), The New Basel Capital Accord, Consultative Document, January 2001, BIS, www.bis.org.

Cantor, R., and F. Packer (1994), The Credit Rating Industry, Quarterly Review, Federal Reserve Bank of New York, Vol. 19 (Summer-Fall), pp. 1-26.

Cantor R., and F. Packer (1995), Sovereign Credit Ratings, Current Issues in Economics and Finance, Federal Reserve Bank of New York, June 1995.

Cantor, R., and F. Packer (1996), Determinants and Impacts of Sovereign Credit Ratings, Economic Policy Review, Federal Reserve Bank of New York, Vol. 2

(October), pp. 37-53.

Caouette, J.B., E. I. Altman, and P. Narayanan (1998), Managing Credit Risk: The Next Great Financial Challenge.

Fitch IBCA (1998), Asia: Agencies' Harsh Lessons in a Crisis, press release, 13 January 1998, www.bradynet.com/e312.html

Huhne, C. (1998), How the Rating Agencies Blew It on Korea, International Economy, Vol. 12 (May/June), pp. 46-63.

IMF (1999), International Capital Markets: Developments, Prospects, and Key Policy Issues, World Economic and Financial Surveys (Washington), Chapter 5, Annex 5 and 6, www.imf.org/external/pubs/ft/icm/1999/index.htm.

Jüttner, J. D., and J. McCarthy (1998), Modeling a Ratings Crisis (unpublished, Sydney, Australia: Macquarie University), www.econ.mq.edu.au/courses/econ360/Soveig1.pdf

Kaminsky, Graciela and Sergio Schmukler, 2002, Emerging Markets Instability: Do Sovereign Ratings Affect Country Risks and Stock Returns? Forthcoming, World Bank Economic Review

Larrain G., H. Reisen, J. von Maltzan (1997), Emerging market risk and sovereign credit ratings, OECD Technical Papers no. 124, www.oecd.org/pdf/M00006000/M00006202.pdf

Moody's Investor Service (2001), Default and Recovery Rates of Corporate Bond Issuers: 2000, Special Comment (February). 
Nagy, P.J. (1984), Country Risk: How to Assess, Quantify, and Monitor it, Euromoney publications, London.

Reisen H., and J. von Maltzan (1999), Boom and Bust in sovereign ratings, OECD

Technical Papers no. 148, www.oecd.org/pdf/M00006000/M00006204.pdf

Standard \& Poor's (1998), Sovereign Credit Ratings: A Primer (December).

Standard \& Poor's (2000), Sovereign 1999 Recap: The Ups, the Downs, and the moral of it all (January). 


\section{Appendix 1: Definition and Measurement of Economic Capital}

Economic capital is part of an integrated portfolio approach by banks, to manage their (credit) risk. The basis for this approach is that diversification of credit portfolio reduces risk (a parallel can be drawn with the portfolio theory by Markowitz). As banks focused too much on individual loans in the past, excessive concentrations often resulted in excessive loss experience.

The economic capital approach distinguishes expected from unexpected losses. Expected losses are long-run estimates of losses of exposure. These can be reflected in loan pricing (together with a capital charge for unexpected losses). Unexpected losses require capital to be set aside to absorb shocks, so that the bank will not experience financial stress by their occurrence..$^{15}$ It should be seen as the maximum potential loss, i.e. the maximum loss given the level of confidence, as calculated by the distribution of the portfolio.

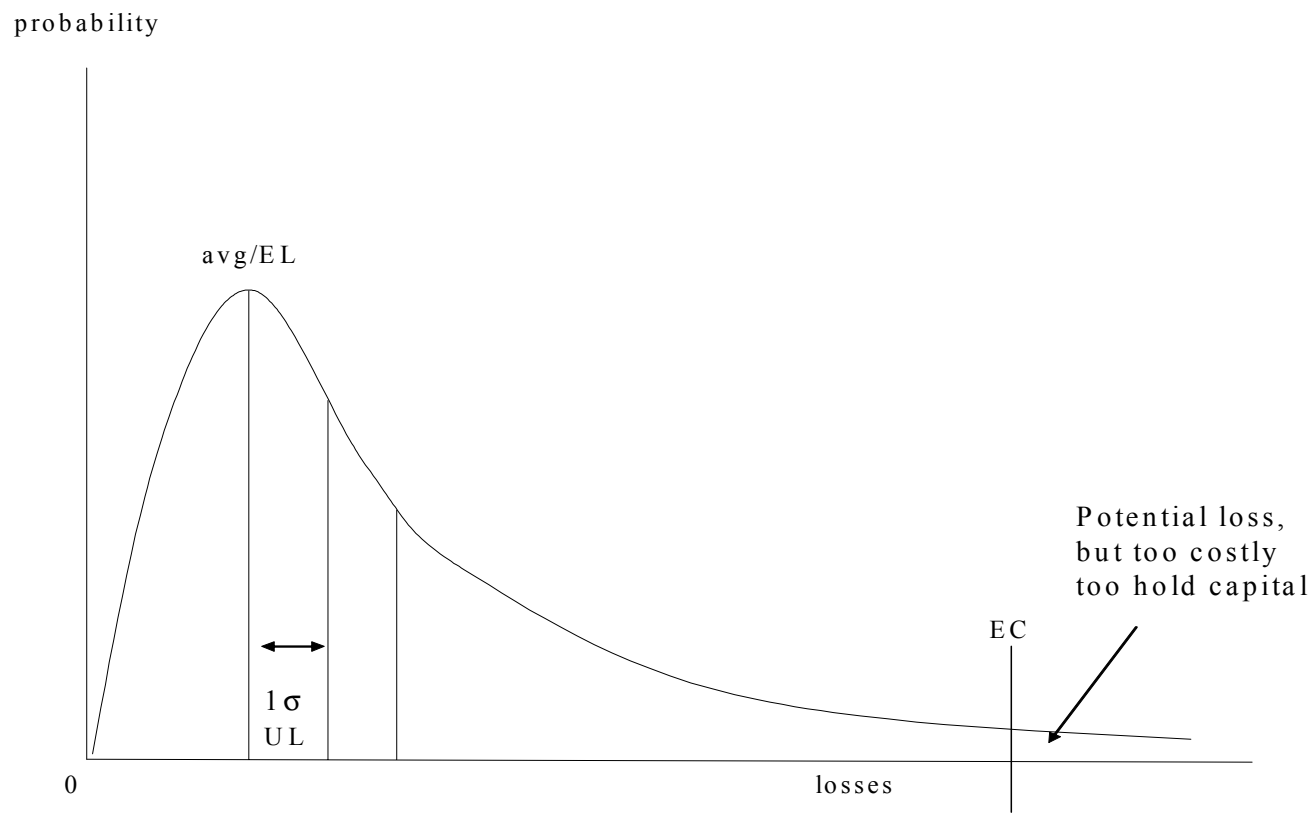

The expected loss is associated with the mean of the loss distribution of loan or a portfolio. The unexpected loss is the loss that is associated with the $99.9 \%$ (for instance) of the area of the loss curve. The area to the right is expected with such a rarity that it would be uneconomical to hold a 100\% capital against contingency.

The economic capital approach uses four factors to determine the expected losses:

1) Expected default probability or Expected default frequency (EDF)

2) Loss Given Default (LGD)

3) Exposure at Default (EAD)

4) Maturity/tenor

15 See J.B. Caouette et. al. (1998), p. 242. 
The Expected Loss (EL) is defined as:

$\mathrm{EL}=\mathrm{EDF}_{\text {tenor }} * \mathrm{EAD} * \mathrm{LGD}$

with Default Probability (DP) linked to ratings and Loss Given Default (LGD) based on the type of transaction/product and collateral. There are several ways to calculate default probabilities, e.g. constructing rating migration matrices on the basis of rating behavior in the past, using bond spreads etc. mapping ratings from the rating agencies.

The EL applied to transfer risk can be calculated as:

$\mathrm{EL}_{\text {Transfer risk }}=$ Transfer Event Probability $_{\text {tenor }} *$ Transfer Risk Exposure at Default $*$ Loss Given Transfer Event

Assets are divided into subclasses of varying risk and the LGTE can be estimated partly by country risk rating category (a high income or low income country) and partly on a basis of past experience in (sovereign) workouts. Factors that contribute to lower risk should be short tenor, export financing, co-financing with multilateral agencies, and local currency denomination.

The calculation of the unexpected loss is driven by the volatility of the expected loss. Apart from the described components (EDF, LGD, EAD) an additional correlation factor is added. A commonly used measure for volatility is $\sqrt{E D F-E D F^{2}}$. Using this measure, the Unexpected Loss can be calculated as follows:

$$
U L=\sqrt{E D F-E D F^{2}} * E A D * L G D * \rho_{i} / \sqrt{\rho_{\text {bank }}}
$$

where

$\begin{array}{ll}\text { EAD } & =\text { Exposure At Default } \\ \rho_{i} & =\text { Default Correlation of Country } i \text { to the total bank portfolio } \\ \rho_{\text {bank }} & =\text { The average Transfer Default Correlation of the total bank portfolio }\end{array}$

A capital multiplier will then multiply this unexpected loss. This multiplier depends on the rating of the bank and the credit portfolio of the bank. In the case of transfer risk, correlation between transfer ratings (this is in effect 'country correlation') has to be taken into account. 


\begin{tabular}{|c|c|c|c|c|}
\hline \multicolumn{5}{|c|}{$\begin{array}{c}\text { Appendix 2, Table 1: Determinants of Sovereign Credit Ratings } \\
\text { (Cantor and Packer regressions) } \\
\text { (absolute t-statistics in parentheses) }\end{array}$} \\
\hline $\begin{array}{c}\text { Explanatory } \\
\text { Variable }\end{array}$ & Average Ratings & Moody's & S\&P & $\begin{array}{c}\text { Rating } \\
\text { difference }\end{array}$ \\
\hline Intercept & $\begin{array}{c}1.442 \\
(0.633)\end{array}$ & $\begin{array}{c}3.408 \\
((1.379)\end{array}$ & $\begin{array}{c}-0.524 \\
(0.223)\end{array}$ & $\begin{array}{l}3.932 * * \\
(2.521)\end{array}$ \\
\hline Per capita income & $\begin{array}{c}1.242 * * * \\
(5.302)\end{array}$ & $\begin{array}{c}1.027 * * * \\
(4.041)\end{array}$ & $\begin{array}{c}1.458 * * * \\
(6.048)\end{array}$ & $\begin{array}{c}-0.431 * * * \\
(2.688)\end{array}$ \\
\hline GDP growth & $\begin{array}{l}0.151^{*} \\
(1.935)\end{array}$ & $\begin{array}{c}0.130 \\
(1.545)\end{array}$ & $\begin{array}{c}0.171 * * \\
(2.132)\end{array}$ & $\begin{array}{l}-0.040 \\
(0.756)\end{array}$ \\
\hline Inflation & $\begin{array}{c}-0.611 * * * \\
(2.839)\end{array}$ & $\begin{array}{c}-0.630 * * * \\
(2.701)\end{array}$ & $\begin{array}{c}-0.591 * * * \\
(2.671)\end{array}$ & $\begin{array}{l}-0.039 \\
(0.265)\end{array}$ \\
\hline Fiscal balance & $\begin{array}{c}0.073 \\
(1.324)\end{array}$ & $\begin{array}{c}0.049 \\
(0.818)\end{array}$ & $\begin{array}{l}0.097^{*} \\
(1.71)\end{array}$ & $\begin{array}{c}-0.048 \\
(1.274)\end{array}$ \\
\hline External balance & $\begin{array}{c}0.003 \\
(0.314)\end{array}$ & $\begin{array}{c}0.006 \\
(0.535)\end{array}$ & $\begin{array}{c}0.001 \\
(0.046)\end{array}$ & $\begin{array}{c}0.006 \\
(0.779)\end{array}$ \\
\hline External debt & $\begin{array}{c}-0.013 * * * \\
(5.088)\end{array}$ & $\begin{array}{c}-0.015 * * * \\
(5.365)\end{array}$ & $\begin{array}{c}-0.011 * * * \\
(4.236)\end{array}$ & $\begin{array}{c}-0.004 * * \\
(2.133)\end{array}$ \\
\hline Ec. Development & $\begin{array}{c}2.776^{* * *} * \\
(4.25)\end{array}$ & $\begin{array}{c}2.957 * * * \\
(4.175)\end{array}$ & $\begin{array}{c}2.595 * * * \\
(3.861)\end{array}$ & $\begin{array}{l}0.362 \\
(0.81)\end{array}$ \\
\hline Default history & $\begin{array}{c}-2.042 * * * \\
(3.175)\end{array}$ & $\begin{array}{c}-1.463 * * \\
(2.097) \\
\end{array}$ & $\begin{array}{c}-2.622 * * * \\
(3.962)\end{array}$ & $\begin{array}{c}1.159 * * * \\
(2.632)\end{array}$ \\
\hline Adjusted $\mathrm{R}^{2}$ & 0.924 & 0.905 & 0.926 & 0.251 \\
\hline Standard error & 1.222 & 1.325 & 1.257 & 0.836 \\
\hline
\end{tabular}

Source: Cantor and Packer (1996), table 5

*Significant at $10 \%$ level **Significant at 5\% level

$* * *$ Significant at $1 \%$ level 
Appendix 2, Table 2: Countries used in the transfer rating analysis

\begin{tabular}{|c|c|c|}
\hline Algeria & $X$ & $X$ \\
\hline Argentina & $X$ & $X$ \\
\hline Bahrain & $X$ & $X$ \\
\hline Bangladesh & $X$ & $X$ \\
\hline Botswana & $X$ & $X$ \\
\hline Brazil & $X$ & $X$ \\
\hline Cameroon & $X$ & $X$ \\
\hline Chile & $X$ & $X$ \\
\hline China & $X$ & $X$ \\
\hline Colombia & $X$ & $X$ \\
\hline Costa Rica & $X$ & $X$ \\
\hline Côte d'Ivoire & $X$ & $X$ \\
\hline Cuba & & $X$ \\
\hline Cyprus & $X$ & $X$ \\
\hline Ecuador & $X$ & $X$ \\
\hline Egypt & $X$ & $X$ \\
\hline Ghana & $X$ & $X$ \\
\hline Greece & $X$ & $X$ \\
\hline Guatemala & $X$ & $X$ \\
\hline Honduras & $X$ & $X$ \\
\hline Hungary & $X$ & $X$ \\
\hline Iceland & $X$ & $X$ \\
\hline India & $X$ & $X$ \\
\hline Indonesia & $X$ & $X$ \\
\hline Iran & $X$ & $X$ \\
\hline Iraq & & $X$ \\
\hline Israel & $X$ & $X$ \\
\hline Jordan & $X$ & $X$ \\
\hline Kenya & $X$ & $X$ \\
\hline Kuwait & $X$ & $X$ \\
\hline Malta & $X$ & $X$ \\
\hline Malaysia & $X$ & $X$ \\
\hline Mexico & $X$ & $X$ \\
\hline Morocco & $X$ & $X$ \\
\hline Nicaragua & $X$ & $X$ \\
\hline Oman & $X$ & $X$ \\
\hline Pakistan & $X$ & $X$ \\
\hline Panama & $X$ & $X$ \\
\hline Paraguay & $X$ & $X$ \\
\hline Peru & $X$ & $X$ \\
\hline Philippines & $X$ & $X$ \\
\hline Poland & $X$ & $X$ \\
\hline Portugal & $X$ & $X$ \\
\hline
\end{tabular}




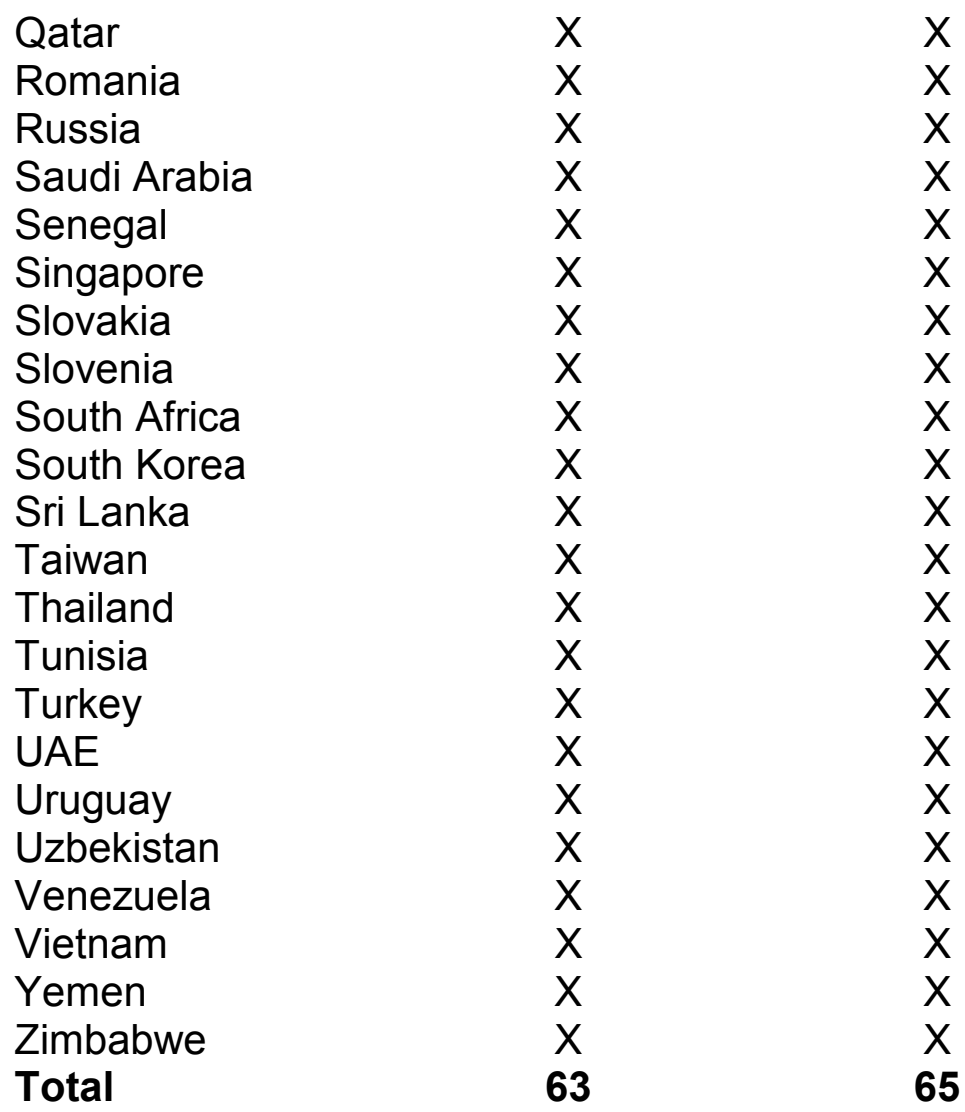

